\title{
Molecular epidemiology of malaria parasite amongst patients in a displaced people's camp in Sudan
}

\author{
Hamza Adam Eshag ${ }^{1}$, Elfadel Elnzer', Elkhatieb Nahied', Mustafa Talib', Ali Mussa', Abd Elhafiz M. A. Muhajir ${ }^{1}$, \\ Ibrahim Khider Ibrahim², Abdulwali Sabo ${ }^{3}$, Salah-Eldin Gumma Elzaki ${ }^{4}$, Zeehaida Mohamed $^{5}$ and \\ Khalid Hajissa ${ }^{1,5^{*}}$ (D)
}

\begin{abstract}
Background: Despite the importance of epidemiological studies in the development of effective control strategies and provision of basic health services for refugees and internally displaced persons (IDPs), data on the prevalence of malaria are limited. Thus, this study was conducted to estimate the molecular prevalence of malaria amongst the displaced population in Ardamata IDP camp in Al-Geneina City, Sudan.

Methods: A cross-sectional study was conducted from July 2018 to December 2018 to estimate malaria prevalence amongst the displaced population in Ardamata IDP camp in Al-Geneina City, Sudan. A total of 380 patients with suspected malaria were recruited. Nested polymerase chain reaction (nPCR) assays were performed to detect the Plasmodium genus and species.

Results: Of 380 patients, 232 (61.1\%) were positive for malaria. Plasmodium falciparum was the only prevalent species detected amongst the study population. nPCR analysis revealed that none of the samples had Plasmodium vivax, Plasmodium ovale or Plasmodium malariae. The malaria prevalence rate was higher amongst males (67.1\%) than in females (56.8\%), and gender was the only risk factor that was significantly associated with malaria infection $(p=.042)$.
\end{abstract}

Conclusions: Despite control programmes, malaria remains a significant cause of illness amongst a displaced population. The high prevalence of malaria infection in this study indicates that additional health facilities and control strategies should be implemented in displaced camps and the surrounding areas.

Keywords: Malaria, Plasmodium, Molecular epidemiology, Displaced camp, Sudan, Nested PCR

\section{Background}

Malaria is a fatal vector-borne tropical disease that remains one of the leading causes of death in many developing countries [1]. The disease continues to pose global public health challenges, and its related morbidity and mortality remain significantly high in endemic countries such as Sudan. Although intensive control measures in recent years have resulted in a substantial reduction in the disease burden, the limited control options and

\footnotetext{
*Correspondence: Khalid541983@yahoo.com; khalidhaj@usm.my

'Department of Zoology, Faculty of Science and Technology, Omdurman Islamic University, B.O.Box 382, Omdurman, Sudan

${ }^{5}$ Department of Medical Microbiology \& Parasitology, School of Medical Sciences, Universiti Sains Malaysia, 16150 Kubang Kerian, Kelantan, Malaysia Full list of author information is available at the end of the article
}

availability of resources due to the violent conflict in Darfur maintain the high risk of malaria in displaced camps; vulnerability to malaria might be promoted by many factors including decimated health care infrastructure and social disruption, making the disease responsible for most cases of death [2]. The high prevalence of malaria in displaced populations in Africa constitutes an emerging challenge for humanitarian response as the disease becomes a serious health problem amongst internally displaced persons (IDPs) in these areas. In Sudan, malaria is one of the most concerning infectious diseases amongst displaced populations, and data on malaria prevalence in displaced camps are extremely limited. Additional epidemiological information is 
required for the development of effective control strategies and provision of basic health services, because the overall aim of any epidemiological study is to prevent and reduce excess mortality and morbidity. According to the World Health Organisation, five Plasmodium species have been recognised as the causative agents of malaria that can infect humans: Plasmodium falciparum ( $P$. falciparum), Plasmodium vivax (P. vivax), Plasmodium ovale (P. ovale), Plasmodium malariae (P. malariae) and Plasmodium knowlesi (P. knowlesi). Of these five species, $P$. falciparum and $P$. vivax are the most common in Sudan.

Blood film microscopy and rapid diagnostic tests are the mainstay of malaria diagnosis that can adequately detect Plasmodium infections in patients with high levels of parasitaemia [3, 4]. However, both methods lack the sensitivity to detect the infection in individuals carrying low parasite density [5, 6]. Given that low-grade parasitaemia in asymptomatic individuals can persist for a year or more, important sources of further transmission must be considered. Recent reports showed that sub-microscopic infections represent about $70-80 \%$ of all Plasmodium infections amongst children, pregnant women and non-pregnant adults [7]. Thus, highly sensitive diagnostic methods are necessary. In recent years, several molecular methods have been developed and evaluated for the detection of Plasmodium species, and various sensitivities and specificities have been reported [1]. Amongst them, polymerase chain reaction (PCR) is the most frequently used method in the field [8]. PCR has also been helpful in the differential detection of all malaria parasites up to species levels, thereby revealing the high prevalence of mixed infections $[1,9]$. The application of sensitive methods such as PCR to determine the prevalence of Plasmodium species will allow better documentation of malaria epidemiology [10] and overcome the lack of knowledge on the prevalence of malaria infection in the displaced population. This study was proposed to determine the molecular prevalence of malaria parasites amongst symptomatic patients in Ardamata IDP camp, Al-Geneina City, Sudan.

\section{Methods}

\section{Study setting}

This study was carried out in Ardamata IDP camp established in Al-Geneina City, which is the capital city of West Darfur State, the western part of Sudan. It is located in the latitude of $13^{\circ} 27^{\prime} 15^{\prime \prime}$ and longitude of $22^{\circ} 26^{\prime} 8^{\prime \prime}$. Al-Geneina is approximately $1200 \mathrm{~km}$ from the capital city of Khartoum.

\section{Study design and population}

This study was a cross-sectional study that recruited patients presenting clinical symptoms of malaria and visiting the health centre in the study site. A total of 380 patients were recruited for this study between July and December 2018.

\section{Samples size calculation}

The sample size was estimated using formula for single proportion to estimate the prevalence of malaria.

$$
\left(\frac{z}{m}\right) 2 \times \mathrm{p}(1-\mathrm{p})
$$

The parameters used were $z=1.96$ (for 0.05 level of significance), margin of error $(\mathrm{m})=0.05, p=0.575$ and 0.33 for $P$. falciparum and $P$. vivax respectively [11]. The calculated sample size was 376 and 340 for $P$. falciparum and $P$. vivax respectively. Hence, the largest sample size based on $P$. falciparum (376) was used. After adding 5\% dropout rate, the adjusted samples size was estimated as 396 .

\section{Sample collection}

About 3-5 drops of blood from each enrolled participant were collected on Whatman No. 1 filter paper. The blood samples were allowed to dry, kept in individual plastic bags with desiccant and stored at room temperature. An informed consent questionnaire was used to collect individual socio-demographic data.

\section{DNA extraction}

DNA was extracted from three $3 \mathrm{~mm}$ punches of dried blood spot (DBS) following the protocol of Bereczky et al. [12]. DNA was eluted in a total volume of $50 \mu \mathrm{l}$ of tri-EDTA buffer (TE) buffer and stored at $-20{ }^{\circ} \mathrm{C}$.

\section{PCR for Plasmodium detection}

Nested PCR (nPCR) was performed as described previously [13] in a two-step procedure. In the first PCR round, amplification was performed using rPLU1 and rPLU5 primers for Plasmodium genus determination. The PCR mixture was prepared in a total volume of $20 \mu \mathrm{l}$, containing $10 \mu \mathrm{l}$ of $\mathrm{MyTaq}^{\mathrm{mm}}$ mix (Bioline, UK), $0.4 \mu \mathrm{M}$ of each primer and $2.5 \mu \mathrm{l}$ of extracted DNA. PCR was performed under the following conditions: $94{ }^{\circ} \mathrm{C}$ for $5 \mathrm{~min}$ as the initial denaturation step; 25 cycles at $94{ }^{\circ} \mathrm{C}$ for $45 \mathrm{~s}, 58{ }^{\circ} \mathrm{C}$ for $45 \mathrm{~s}$ and $72{ }^{\circ} \mathrm{C}$ for $1 \mathrm{~min}$; and a final extension step at $72{ }^{\circ} \mathrm{C}$ for $5 \mathrm{~min}$. The amplified PCR product $(1 \mu \mathrm{l})$ was used as a template for the second PCR round for Plasmodium species identification using (rFAL1 and rFAL2, rOVA-1 and rOVA2, rVIV1 and rVIV2, rMAL1 and rMAL2) primers [13]. The reaction mix contained $10 \mu \mathrm{l}$ of MyTaq $^{\text {Tim }}$ mix (Bioline, UK) and $0.4 \mu \mathrm{M}$ of each primer, and the final reaction volume was made up to $20 \mu \mathrm{l}$ by adding double distilled water. Amplification was performed under the following conditions: $95{ }^{\circ} \mathrm{C}$ for $5 \mathrm{~min}$; 30 cycles of $94{ }^{\circ} \mathrm{C}$ for $1 \mathrm{~min}, 58^{\circ} \mathrm{C}$ for $2 \mathrm{~min}$ and $72{ }^{\circ} \mathrm{C}$ for 
$5 \mathrm{~min}$; and final extension at $72{ }^{\circ} \mathrm{C}$ for $2 \mathrm{~min}$. A known Plasmodium positive samples and a negative control sample without DNA template was used in all the reactions as positive and negative control respectively.

\section{Data analysis}

Preliminary data analysis was conducted for data exploration and cleaning to check for missing values and erroneous data entry. The statistical analysis applied in the current study was descriptive analysis and logistic regression analysis. Descriptive analysis focused on frequency, percentages, mean and standard deviation. Logistic regression analysis was conducted to identify significant factors associated with the outcome of malaria infection. All statistical analyses were conducted using SPSS 24.

\section{Results}

\section{Socio-demographic characteristics of the study participants}

Table 1 shows the descriptive characteristics of the participants. A total of 380 patients with clinical suspicion of malaria were enrolled in this study. Approximately $96.1 \%$ $(n=365)$ of the participants were residents of Ardamata IDP camp. Amongst the study participants, $41.6 \%(n=$ $158)$ were males and $58.4 \%(n=222)$ were females. Their ages ranged from 1 to 80 years, and the mean age was 21.7 years $(\mathrm{SD}=14.1)$. The majority of the participants $(59.5 \%, n=226)$ belonged to the $<20$ age group. More than half of the participants were single $(58.9 \%, n=224)$. Majority of them $(44.5 \%, n=169)$ reported receiving primary school education, whereas $34.7 \%(n=132)$ were illiterate. The monthly income was $<20$ USD for $14.5 \%$ ( $n=55), 20-25$ USD for $46.6 \%$ ( $n=177), 25-30$ USD for $20 \%(n=76)$ and more than 30 USD for $18.9 \%(n=72)$. Approximately $97.9 \%(n=372)$ of the patients with suspected malaria had mosquito nets.

\section{Prevalence of malaria infection and the associated risk factors}

Molecular analysis showed that approximately $61.1 \%$ (232 out of 380) of analysed samples were positive for malaria (Table 1). P. falciparum was the only prevalent species found amongst the study population (Fig. 1). None of the samples had $P$. vivax, $P$. ovale or $P$. malariae. The prevalence of malaria infection was higher in males $(67.1 \%)$ than in females $(56.8 \%)$. Gender had a statistically significant association with malaria infection (crude odds ratio $[\mathrm{COR}]=1.55, p=.042$ ), indicating that the males were 1.5 times more likely to have malaria infection than the females. None of the remaining factors demonstrated any significant association with malaria infection (Table 2).). For example, the unadjusted crude odds ratio of age indicated that those who are 21 years and above were $11 \%$ less likely to have malaria infection
Table 1 General and socio-demographic characteristics of participants

\begin{tabular}{|c|c|c|c|c|}
\hline Variables & Categories & Frequency & Percentage & $\begin{array}{l}\text { Mean } \\
(\mathrm{SD})\end{array}$ \\
\hline \multirow[t]{2}{*}{ Residence } & Resident & 365 & 96.1 & \\
\hline & Visitor & 15 & 3.9 & \\
\hline \multirow[t]{2}{*}{ Gender } & Male & 158 & 41.6 & \\
\hline & Female & 222 & 58.4 & \\
\hline Age & & & & $21.7(14.1)$ \\
\hline \multirow[t]{3}{*}{ Occupation } & $\begin{array}{l}\text { None (student } \\
\text { and retired) }\end{array}$ & 252 & 66.3 & \\
\hline & $\begin{array}{l}\text { Self-employed } \\
\text { (farming and other) }\end{array}$ & 114 & 30 & \\
\hline & Gov. employee & 14 & 3.7 & \\
\hline \multirow{2}{*}{$\begin{array}{l}\text { Marital } \\
\text { status }\end{array}$} & Married & 156 & 41.1 & \\
\hline & Single & 224 & 58.9 & \\
\hline \multirow{4}{*}{$\begin{array}{l}\text { Monthly } \\
\text { income }\end{array}$} & $<20$ USD & 55 & 14.5 & \\
\hline & 20-25 USD & 177 & 46.6 & \\
\hline & 25-30 USD & 76 & 20 & \\
\hline & $>30$ USD & 72 & 18.9 & \\
\hline \multirow{4}{*}{$\begin{array}{l}\text { Education } \\
\text { level }\end{array}$} & Illiterate & 132 & 34.7 & \\
\hline & Primary & 169 & 44.5 & \\
\hline & Secondary & 59 & 15.5 & \\
\hline & $\begin{array}{l}\text { Graduate and } \\
\text { above }\end{array}$ & 20 & 5.3 & \\
\hline \multirow[t]{2}{*}{ Fever } & No & 69 & 18.2 & \\
\hline & Yes & 311 & 82.8 & \\
\hline \multirow[t]{2}{*}{ Joint pain } & No & 256 & 67.4 & \\
\hline & Yes & 124 & 32.6 & \\
\hline \multirow{2}{*}{$\begin{array}{l}\text { Mosquito } \\
\text { net }\end{array}$} & No & 8 & 2.1 & \\
\hline & Yes & 372 & 97.9 & \\
\hline \multirow[t]{2}{*}{ Malaria PCR } & Negative & 148 & 38.9 & \\
\hline & Positive & 232 & 61.1 & \\
\hline
\end{tabular}

than the 20 years and below group $(\mathrm{COR}=0.89, p$ value $=0.579$ ).

\section{Discussion}

Malaria remains one of the significant health problems in the tropical and subtropical poorest nations [14]. In Sudan, the disease is endemic, and previous studies reported a relatively high burden of the disease in many areas of the country. In this study, blood samples were collected from patients suspected to have malaria at Ardamata IDP camp. Genus- and species-specific nPCR was used as a diagnostic tool to detect the malaria parasites. A high prevalence of the malaria parasites (61.1\%) was detected amongst the study participants. This percentage was remarkably high compared with the low prevalence of malaria infection detected by microscope 


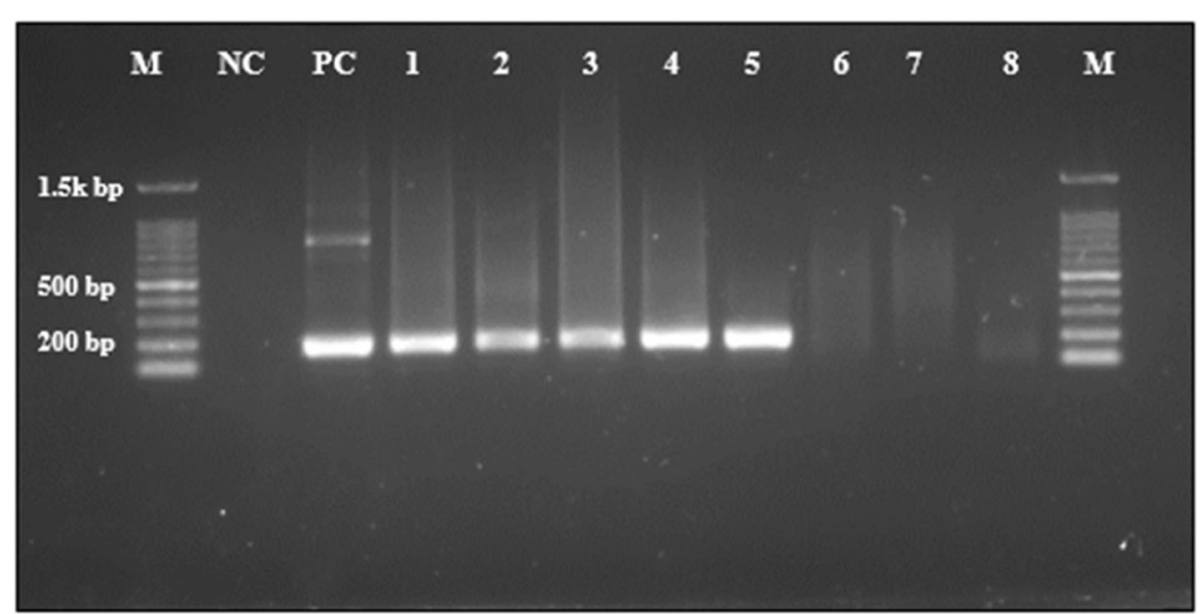

Fig. 1 DNA amplification of Plasmodium species by nPCR. Lane M: 100 bp DNA Marker. Lane NC: negative control. Lane PC: positive control. Lane 1-5: positive samples for $P$. falciparum t. Lane 6-8: negative control

in Dar Alsalam (5\%) and Jabal Awlia (11\%) camps [15], which are located in Khartoum state. This low infection rate could be attributed to the prevention and control activities of malaria in these areas. However, when a similar diagnostic method was used (nPCR), high prevalence of Plasmodium parasites was also detected amongst patients with suspected malaria recruited from different clinics in Omdurman area [16] and Kosti [17] $(44.1 \%$ and $32 \%)$, respectively. The significantly high burden of malaria infection in this study may have coincided with the limited control options and availability of resources in the displaced camp. It may also be a result of the timing of sample collection due to the malaria transmission season.

Similarly, the discrepancy in disease epidemiology was also reported in other African countries. A study conducted in Ethiopia, a malaria-endemic country, revealed that the overall prevalence rate of malaria detected by microscopy was $18.4 \%$ [18]. The molecular detection of malaria parasite in Democratic Republic of Congo and Nigeria demonstrated that the infection rate of the disease was $34.9 \%$ [8] and $58.7 \%$ respectively [10].

In endemic areas, determination of the epidemiological pattern of the malaria infection is crucial for intervention programmes and treatment purposes. Accordingly, all the main malaria species that infect humans have been previously reported in the country [19], with a predominance of $P$. falciparum malaria and relatively rare $P$. vivax infection in regions of the study. However, most of the recent studies indicated changes in the epidemiological pattern, and a high proportion of $P$. vivax infections was reported [20]. The results of the current study revealed a high infection rate of $P$. falciparum malaria. This elevated prevalence amongst the overall study population has also been reported by previous research
[21]. None of the samples of the present study were positive for $P$. vivax, $P$. ovale and $P$. malariae. However, many previous studies have demonstrated the presence of non- $P$. falciparum elsewhere in the country, either through single or mixed infections. For instance, out of 283 malaria-positive cases, Ageep (2013) reported that $50.2 \%$ was $P$. falciparum, $43.8 \%$ was $P$. vivax, $04.9 \%$ was $P$. ovale and $1.1 \%$ of the cases was P. malariae; no mixed infection was observed [19]. Recently, a remarkable increase in the recurrent relapses of malaria infections was observed in different areas in Sudan, thereby indicating a high infection rate of $P$. vivax malaria and making $P$. vivax the second important species in the country [11]. Another recent study showed that the occurrence of $P$. vivax malaria is high amongst suspected malaria cases, with a prevalence of $26.6 \%$ [20]. In general, the variation in the overall prevalence and species-specific malaria might be due to differences in the geography of the study area, sample size used, timing of sample collection, climate condition, study subjects, environmental factors and many other factors involved [22].

Univariate regression analysis of the risk of having malaria in suspected symptomatic participants showed that only gender was significantly associated with malaria $(\mathrm{COR}=1.55, p=.042)$, and none of the remaining factors had any significant influence (Table 2).

The prevalence of malaria infection in relation to gender indicated that the males were $1.5 \%$ more likely to have malaria infection than the females. The higher prevalence observed amongst males in this study was in agreement with the findings of previous reports that showed predominance of malaria infection in males [23, 24] but contradicted other studies [25, 26]. Some hypotheses justify the increased infection rate amongst males by the fact that they are more likely 
Table 2 Factors associated with test positivity for malaria

\begin{tabular}{|c|c|c|c|c|c|}
\hline \multirow[t]{2}{*}{ Characteristics } & \multicolumn{5}{|l|}{ Test positivity } \\
\hline & Total No. (\%) & Negative No. (\%) & Positive No. (\%) & Crude OR (95\% Cl) & $P$ value \\
\hline \multicolumn{6}{|l|}{ Residence } \\
\hline Resident & $365(96.1)$ & $142(38.9)$ & $223(61.1)$ & $1.047(0.37,3.00)$ & .932 \\
\hline Visitor & $15(3.9)$ & $6(40.6)$ & $9(60.0)$ & 1 & \\
\hline \multicolumn{6}{|l|}{ Gender } \\
\hline Male & $158(41.6)$ & $52(32.9)$ & $106(67.1)$ & $1.55(1.02,2.38)$ & .042 \\
\hline Female & $222(58.4)$ & $96(43.2)$ & $126(56.8)$ & 1 & \\
\hline \multicolumn{6}{|l|}{ Age group } \\
\hline$\leq 20$ years & $230(60.5)$ & $87(37.8)$ & $143(62.2)$ & 1 & \\
\hline$\geq 21$ years & $150(39.5)$ & $61(40.7)$ & $89(59.3)$ & $0.89(0.58,1.35)$ & 0.579 \\
\hline \multicolumn{6}{|l|}{ Occupation } \\
\hline None (student and retired) & $252(66.3)$ & $101(40.1)$ & $151(59.9)$ & 1 & \\
\hline Self-employed (farming and other) & $114(30.0)$ & $41(36.0)$ & $73(64.0)$ & $1.19(0.75,1.88)$ & 0.445 \\
\hline Gov. employee & $14(3.7)$ & $6(42.9)$ & $8(57.1)$ & $0.89(0.30,2.65)$ & .837 \\
\hline \multicolumn{6}{|l|}{ Monthly income } \\
\hline$<20$ USD & $55(14.5)$ & $18(32.7)$ & $37(67.3)$ & 1 & \\
\hline $20-25$ USD & $177(46.6)$ & $75(42.4)$ & $102(57.6)$ & $0.66(0.35,1.25)$ & .204 \\
\hline 25-30 USD & $76(20)$ & $23(30.3)$ & $53(69.7)$ & $1.12(0.53,2.36)$ & .764 \\
\hline$>30$ USD & 72 (18.9) & $32(44.4)$ & 40 (55.6) & $0.61(0.29,1.26)$ & .182 \\
\hline \multicolumn{6}{|l|}{ Marital status } \\
\hline Married & $156(41.1)$ & $60(38.5)$ & $96(61.5)$ & 1 & \\
\hline Single & $224(58.9)$ & $88(39.3)$ & $136(60.7)$ & $0.97(0.64,1.47)$ & .871 \\
\hline \multicolumn{6}{|l|}{ Education level } \\
\hline Illiterate & $132(34.7)$ & $49(37.1)$ & $83(62.9)$ & 1 & \\
\hline Primary & $169(44.5)$ & $69(40.8)$ & $100(59.2)$ & $0.86(0.54,1.37)$ & .513 \\
\hline Secondary & $59(15.5)$ & $23(39.0)$ & $36(61.0)$ & $0.92(0.49,1.730$ & .806 \\
\hline Graduate and above & $20(5.3)$ & $7(35.0)$ & $13(65.0)$ & $1.10(0.41,2.93)$ & .855 \\
\hline \multicolumn{6}{|l|}{ Fever } \\
\hline No & $69(18.2)$ & $29(42.0)$ & $40(58.0)$ & 1 & \\
\hline Yes & $311(81.8)$ & $119(38.3)$ & $192(61.7)$ & 1.170 & .562 \\
\hline \multicolumn{6}{|l|}{ Joint pain } \\
\hline No & $256(67.4)$ & $94(36.7)$ & $162(63.3)$ & 1 & \\
\hline Yes & 124 (32.6) & $54(43.5)$ & $70(56.5)$ & .752 & .201 \\
\hline
\end{tabular}

$C O R$ crude odds ratio, $A O R$ adjusted odds ratio, $\mathrm{Cl}$ confidence interval, $S D$ standard deviation

to work outside compared with females; thus, men are subjected to an increased number of infected mosquito bites than females [27].

In malaria-endemic areas, protective immunity is always correlated with age. A low prevalence of malaria and low incidence of clinical symptoms are frequently observed amongst adults and older children. This concept is in line with the observations of this study, which showed that the odds of being positive for malaria decreased by $11 \%$ amongst those who are $\geq 21$ years compared to the $\leq 20$ years $(p$ value $=0.579)$. No associations were found in the present study between malaria infection and the use of insecticide-treated bed net (ITNs). Similarly, education status and marital status did not show any significant association with malaria infection.

These findings were in contrast to other work, which showed that the use of ITNs and many sociodemographic factors are significantly associated with malaria. Recruiting only patients with suspected clinically symptomatic malaria possibly affected the results of this study. Further comprehensive surveys are required 
to identify the factors associated with malaria infection that were not addressed in this study.

\section{Conclusion}

In conclusion, results of this study indicated a high prevalence of malaria amongst the displaced participants. This study further emphasises the necessity to strengthen malaria control strategies and establish additional health facilities.

\section{Abbreviations}

DBS: Dried blood spot; IDPs: Internally displaced persons; ITN: Insecticidetreated bed net; nPCR: Nested polymerase chain reaction; TE: Tri-EDTA buffer

\section{Acknowledgements}

We thank the Department of Epidemiology, Tropical Medicine Research Institute, the National Centre for Research, Khartoum, Sudan, for their invaluable assistance in this study and all patients who agreed to participate in the study.

\section{Authors' contributions}

$\mathrm{KH}, \mathrm{AEM}, \mathrm{ES}, \mathrm{IKI}$, and ZM conceived and designed the study; HAE, AA, EN, MT, and AM conducted field and laboratory work; and AS carried out statistical analysis. All authors read and approved the final manuscript.

\section{Funding}

This study was supported by the Grants of the Commission of Scientific Research and Innovation, Ministry of Higher Education and Scientific Research, Sudan, grant No. SRIC/2017/RP761.

\section{Availability of data and materials}

Any further requested information regarding the experimental and data analysis during the current study is available from the corresponding author on reasonable request.

\section{Ethics approval and consent to participate}

This study was approved by the Ethical Committee of the Research Directorate, General Directorate of planning \& International Health, Federal Ministry of Health, Republic of Sudan ( $\mathrm{fmoh} / \mathrm{nhrc} / \mathrm{rd} / \mathrm{rec}$ ). Written signed informed consent was obtained from each participant or their guardians/ parents before his/her enrolment in the study.

\section{Consent for publication}

Not applicable.

\section{Competing interests}

The authors declare that they have no competing interests.

\section{Author details}

'Department of Zoology, Faculty of Science and Technology, Omdurman Islamic University, B.O.Box 382, Omdurman, Sudan. ${ }^{2}$ Department of Haematology, Faculty of Medical Laboratory Sciences, Al Neelain University, Khartoum, Sudan. ${ }^{3}$ Unit of Biostatistics and Research Methodology, School of Medical Sciences, Universiti Sains Malaysia, Health Campus, 16150 Kubang Kerian, Kelantan, Malaysia. ${ }^{4}$ Department of Molecular Epidemiology, Tropical Medicine Research Institute, National Center for Research, Khartoum, Sudan. ${ }^{5}$ Department of Medical Microbiology \& Parasitology, School of Medical Sciences, Universiti Sains Malaysia, 16150 Kubang Kerian, Kelantan, Malaysia.

Received: 7 October 2019 Accepted: 16 January 2020

Published online: 29 January 2020

\section{References}

1. Lee PC, Chong ETJ, Anderios F, Lim YA, Chew CH, Chua KH. Molecular detection of human Plasmodium species in Sabah using PlasmoNex ${ }^{\text {TM }}$ multiplex PCR and hydrolysis probes real-time PCR. Malar J. 2015;14:28

2. Brooks HM, Paul MKJ, Claude KM, Mocanu V, Hawkes MT. Use and disuse of malaria bed nets in an internally displaced persons camp in the Democratic
Republic of the Congo: a mixed-methods study. PLoS One. 2017;12(9): e0185290.

3. Abeku TA, Kristan M, Jones C, Beard J, Mueller DH, Okia M, Rapuoda B, Greenwood B, Cox J. Determinants of the accuracy of rapid diagnostic tests in malaria case management: evidence from low and moderate transmission settings in the East African highlands. Malar J. 2008;7(1):202.

4. Rougemont M, Van Saanen M, Sahli R, Hinrikson HP, Bille J, Jaton K. Detection of four Plasmodium species in blood from humans by $18 \mathrm{~S}$ rRNA gene subunit-based and species-specific real-time PCR assays. J Clin Microbiol. 2004;42(12):5636-43.

5. Grabias B, Essuman E, Quakyi IA, Kumar S. Sensitive real-time PCR detection of Plasmodium falciparum parasites in whole blood by erythrocyte membrane protein 1 gene amplification. Malar J. 2019;18(1):116.

6. Mwingira F, Genton B, Kabanywanyi A-NM, Felger I. Comparison of detection methods to estimate asexual Plasmodium falciparum parasite prevalence and gametocyte carriage in a community survey in Tanzania. Malar J. 2014;13(1):433.

7. Mbuyi T, Marie L, Bouyou-Akotet MK, Mawili-Mboumba DP. Molecular detection of Plasmodium falciparum infection in matched peripheral and placental blood samples from delivering women in Libreville, Gabon. Malar Res Treat. 2014;2014:486042.

8. Kavunga-Membo H, llombe G, Masumu J, Matangila J, Imponge J, Manzambi E, Wastenga F, Ngoyi DM, Van Geetruyden J-P, Muyembe JJ. Molecular identification of Plasmodium species in symptomatic children of Democratic Republic of Congo. Malar J. 2018;17(1):334.

9. Ehtesham R, Fazaeli A, Raeisi A, Keshavarz H, Heidari A. Detection of mixedspecies infections of Plasmodium falciparum and Plasmodium vivax by nested PCR and rapid diagnostic tests in southeastern Iran. Am J Trop Med Hyg. 2015;93(1):181-5.

10. Oboh MA, Badiane AS, Ntadom G, Ndiaye YD, Diongue K, Ndiaye D. Molecular identification of Plasmodium species responsible for malaria reveals Plasmodium vivax isolates in Duffy negative individuals from southwestern Nigeria. Malar J. 2018;17(1):439.

11. Bereczky S, MÅrtensson A, Gil JP, FÄrnert A. Rapid DNA extraction from archive blood spots on filter paper for genotyping of Plasmodium falciparum. Am J Trop Med Hyg. 2005;72(3):249-51.

12. Singh B, Bobogare A, Cox-Singh J, Snounou G, Abdullah MS, Rahman HA. A genus-and species-specific nested polymerase chain reaction malaria detection assay for epidemiologic studies. Am J Trop Med Hyg. 1999;60(4): 687-92.

13. Sylla K, Tine RCK, Ndiaye M, Sow D, Sarr A, Mbuyi MLT, Diouf I, Lô AC, Abiola A, Seck MC. Sero-epidemiological evaluation of Plasmodium falciparum malaria in Senegal. Malar J. 2015;14(1):275

14. El Mekki MA, Nea'am AA, Alghaithy AA, Elhassan MM. Prevalence and molecular identification of malaria parasite in displaced camps in Khartoum state, Sudan. Egypt Acad J Biol Sci. 2012:4(1):7-12.

15. Mussa A, Talib M, Mohamed Z, Hajissa K. Genetic diversity of Plasmodium falciparum histidine-rich protein 2 (Pf HRP2) and its effect on the performance of Pf HRP2-based rapid diagnostic tests. BMC Res Notes. 2019;2(1):334.

16. Hamid MMA, Mohammed SB, El Hassan IM. Genetic diversity of Plasmodium falciparum field isolates in Central Sudan inferred by PCR genotyping of merozoite surface protein 1 and 2. N Am J Med Sci. 2013;5(2):95.

17. Aschale $Y$, Mengist A, Bitew A, Kassie B, Talie A. Prevalence of malaria and associated risk factors among asymptomatic migrant laborers in West Armachiho District, Northwest Ethiopia. Res Rep Trop Med. 2018;9:95.101.

18. Ageep AK. Diagnosis of malaria in red sea state, Sudan. Ann Trop Med Public Health. 2013:6(2):232.

19. Elgoraish AG, Elzaki SEG, Ahmed RT, Ahmed Al, Fadlalmula HA, Abdalgader Mohamed S, Abdallah NI, Abdelgadir O, Ageep TB, El-Sayed BB. Epidemiology and distribution of Plasmodium vivax malaria in Sudan. Trans R Soc Trop Med Hyg. 2019:4:517-24. https://academic.oup.com/trstmh/ article/113/9/517/5510701.

20. Mustafa SO, Hamid MMA, Aboud MA, Amin M, Muneer MS, Yasin K, Mahgoub NS, El Bagir NM. Genetic diversity and multiplicity of Plasmodium falciparum merozoite surface protein 2 in field isolates from Sudan. F1000Research. 2017;6:1790. https://www.ncbi.nlm.nih.gov/pubmed/?term= Molecular+evidence+of+high+proportion+of+Plasmodium+vivax+malaria+ infection+in+White+Nile+area+in+Sudan.

21. Suliman MMA, Hamad BM, Albasheer MMA, Elhadi M, Amin Mustafa M, Elobied M, Hamid MMA. Molecular evidence of high proportion of 
Plasmodium vivax malaria infection in White Nile area in Sudan. J Parasitol Res. 2016;2016

22. Amenu D. Prevalence of malaria among patients visiting Nekemte hospital. J Med Microb Diagn. 2014;3(2):137.

23. Tadesse F, Fogarty AW, Deressa W. Prevalence and associated risk factors of malaria among adults in east Shewa zone of Oromia regional state, Ethiopia: a cross-sectional study. BMC Public Health. 2018;18(1):25.

24. Nyirakanani C, Chibvongodze R, Habtu M, Masika M, Mukoko D, Njunwa KJ. Prevalence and risk factors of asymptomatic malaria among underfive children in Huye District, Southern Rwanda. Tanzan J Health Res. 2018;20(1). https://www.ajol.info/index.php/thrb/article/view/163139.

25. Ibekwe A, Okonko I, Onunkwo A, Ogun A, Odeze A. Comparative prevalence level of Plasmodium in freshmen (first year students) of Nnamdi Azikwe University in Awka, south-eastern, Nigeria. Malays J Microbiol. 2009;5(1):51-4.

26. Okonko I, Soleye F, Amusan T, Ogun A, Udeze A, Nkang A, Ejembi J, Faleye T. Prevalence of malaria plasmodium in Abeokuta, Nigeria. Malays J Microbiol. 2009;5(2):113-8.

27. Khattak AA, Venkatesan M, Nadeem MF, Satti HS, Yaqoob A, Strauss K, Khatoon L, Malik SA, Plowe CV. Prevalence and distribution of human Plasmodium infection in Pakistan. Malar J. 2013;12(1):297.

\section{Publisher's Note}

Springer Nature remains neutral with regard to jurisdictional claims in published maps and institutional affiliations.

Ready to submit your research? Choose BMC and benefit from:

- fast, convenient online submission

- thorough peer review by experienced researchers in your field

- rapid publication on acceptance

- support for research data, including large and complex data types

- gold Open Access which fosters wider collaboration and increased citations

- maximum visibility for your research: over $100 \mathrm{M}$ website views per year

At $\mathrm{BMC}$, research is always in progress.

Learn more biomedcentral.com/submissions 